\title{
Differences in cow's milk composition between Iceland and the other Nordic countries and possible connections to public health
}

D. Iggman', B Birgisdottir', A Ramel', J Hill ${ }^{2}$ and I. Thorsdottir'

'Unit for Nutrition Research, Landspitali-University Hospital and University of Iceland, Reykjavik, Iceland; ${ }^{2}$ Fonterra Research Centre, Palmerston North, New Zealand

\section{Abstract}

Background: The Icelandic bovine herd has been isolated for over 1100 years. Knowledge is needed about how its milk constituents differ from those of milk in the other Nordic countries, where cattle have been interbred with other European races. As milk and dairy products comprise a substantial part of food intake, especially in children, variations in cow's milk composition may be of value when considering environmental factors in public health. Regional variation in milk composition may explain contradictory results from studies on milk consumption and aetiology of diseases, type 1 diabetes mellitus and cardiovascular disease. Objective: To investigate differences in milk composition, particularly substances suggested to influence public health.

Design: Analyses of the proteins $\beta$-casein and $\beta$-lactoglobulin, as well as fatty acid profiles and nitrates, were performed in samples of cow's milk as sold to consumers, at four different times during 1 year in three different regions in Iceland and in the capital areas of the other countries.

Results: The Icelandic milk was significantly $(p<0.05)$ lower in $\beta$-casein fractions A1 and B and higher in the A 2 fraction, lower in $\beta$-lactoglobulin B and higher in A $(p<0.001)$, had less than half in $n-6 / n-3$ ratio and was higher in the very long-chain n-3 fatty acids and conjugated linoleic acid. It was slightly higher in saturated fatty acids. No significant difference was seen in the total amount of $\beta$-caseins, $\beta$-lactoglobulins or nitrates.

Conclusions: Although slightly higher in saturated fatty acids, the Icelandic milk has a composition of proteins and fatty acids that may be associated with health benefits.

Keywords: $\beta$-Casein, conjugated linoleic acid, $\beta$-lactoglobulin, n-6/n-3 ratio, nutrition

Received: 10 June 2003; Revised: I Sep. 2003; Accepted: 4 Sep. 2003

\section{Introduction}

Possible connections between the consumption of cow's milk and public health have been debated. Suggestions have been made that milk consumption may be involved in the aetiology of several common diseases, but so far little evidence has been presented and studies have often been contradictory. One possible explanation for this is the regional variations in milk constituents. As milk and dairy products comprise a substantial part of food intake, especially in children, these variations may be of value when considering environmental factors in public health. The Nordic countries all have a high per capita consumption of milk, which not only provides a high nutritional value but also contains many bioactive compounds that may influence health.

A previous study (1) found differences in $\beta$-casein fractions between Iceland and the rest of the Nordic countries. This difference has been related to the lower incidence of type 1 diabetes mellitus (DM-1) in Iceland than in the other countries $(1,2)$. Another study (3) showed that the Icelandic milk was higher in bovine serum albumin and immunoglobulins, whereas the amount of lactoferrin was similar to that of the other Nordic countries. In that study no correlation could be found between the consumption of these proteins and the incidence of 
DM-1, although such connections had earlier been suggested.

The Icelandic bovine herd has been isolated for over 1100 years (4), whereas in Denmark, Finland, Norway and Sweden, cattle have been interbred with other European breeds to a large extent (5), with consequent changes in phenotype and milk composition $(4,6)$. The aim of this study was to investigate further the differences in milk composition between Icelandic milk and milk from the other Nordic countries, with a particular interest in substances suggested to influence public health.

A large-scale analysis was conducted, in which milk samples were collected from the five Nordic countries on four different occasions (August, November, February and June), and a large spectrum of bioactive substances, proteins and fatty acids was analysed. The substances highlighted in this study include the genetic protein variants of $\beta$ casein and $\beta$-lactoglobulin, nitrates, the fatty acids $n-3, n-6$ and very long-chain n-3, conjugated linoleic acid (CLA) and the total amount of saturated fatty acids.

\section{Materials and methods}

\section{Milk sampling}

Samples of non-fat, low-fat and full-fat cow's milk as sold to consumers were drawn from Denmark, Finland, Norway and Sweden four times during 1 year (2001-2002) $(n=48)$. Icelandic milk was sampled each time from three different places in Iceland (west, north-east and south; $n=36$ ). The milk samples $(n=84)$ were sent by express delivery to Reykjavik, where they were freeze-dried and sent to New Zealand for analyses.

\section{Fatty acid analyses}

Milk fat content was measured with the method IDF standard 9C:1987. Fatty acids were analysed as fatty acid methyl esters using capillary gas chromatography. The methylation was done according to Christopherson and Glass (7) and Richardson (8). Gas chromatography was based on AOCS Official Method Ce 1e-91. Fatty acids were quantified using methods from Ackman and Sipos (9) and Bannon et al. (10). The CLA content in cow's milk was measured as c9t11-CLA isomer. Fatty acids are expressed in $\mathrm{wt} \%$ of total fatty acids. The content of very long-chain omega 3 fatty acids was calculated as: total n-3 fatty acids - linolenic acid.

\section{Protein analyses}

Caseins were separated and quantified by reversephase high-performance liquid chromatography (HPLC) by a method from Bobe et al. (11). Analysis of genetic variants was performed through capillary electrophoresis, as described previously (12). The contents of $\mathrm{A} 1, \mathrm{~A} 2$ and $\mathrm{B} \beta$-casein variants were given as relative proportions, i.e. fractions. Major whey proteins were determined and quantified by HPLC according to Elgar et al. (13), and were further quantified using capillary zone electrophoresis, as described previously (14).

\section{Statistical analysis}

The Kolmogorov-Smirnov test was used to evaluate normality (two-tailed asymptomatic significance $>0.05)$. The number of samples $(n=21$, of which nine were Icelandic and three from each of the other four countries) was regarded as borderline for parametric testing, so all analyses were double checked with the Mann-Whitney non-parametric test. The results were found, without exception, to be comparable to results from the independent samples $t$-test, which was therefore used. In general, equal variances were assumed. All statistical analyses were performed with SPSS/PC. $p<0.05$ was regarded as statistically significant.

\section{Results}

Table 1 shows the protein fractions of $\beta$-casein and $\beta$-lactoglobulin in Icelandic milk and in milk from the other Nordic countries. For the total amount of $\beta$-casein, no significant difference was found between Iceland and the Nordic countries, but significant differences were found for the individual fractions (Table 1). For the sum of $\mathrm{A} 1+\mathrm{B}(p<$ $0.001)$, the Icelandic milk clearly had lower amounts

Table I. Protein fractions in Icelandic $(n=9)$ versus Nordic milk $(n=12)$

\begin{tabular}{lrcr}
\hline & Iceland & $\begin{array}{l}\text { Other Nordic } \\
\text { countries }\end{array}$ & $\boldsymbol{p}$ \\
\hline$\beta$-Casein total (wt\%) & $11.4 \pm 0.6$ & $11.7 \pm 0.5$ & 0.766 \\
$\beta$-Casein AI & $33.4 \pm 0.3$ & $37.4 \pm 1.0$ & 0.002 \\
$\beta$-Casein A2 & $62.4 \pm 0.4$ & $54.6 \pm 0.9$ & $<0.001$ \\
$\beta$-Casein B & $4.2 \pm 0.2$ & $7.9 \pm 1.1$ & $0.008^{\mathrm{a}}$ \\
$\beta$-Lactoglobulin total (wt\%) & $2.2 \pm 0.1$ & $2.4 \pm 0.1$ & 0.143 \\
$\beta$-Lactoglobulin A & $55.2 \pm 1.1$ & $42.0 \pm 1.3$ & $<0.001$ \\
$\beta$-Lactoglobulin B & $44.8 \pm 1.1$ & $58.0 \pm 1.3$ & $<0.001$ \\
\hline
\end{tabular}

Data are shown as mean \pm SEM.

${ }^{a}$ Equal variances not assumed. 
(37.6 \pm 0.4 vs $45.4 \pm 0.9$; mean \pm SEM). However, an even greater difference was observed in the amount of $\beta$-lactoglobulin $\mathrm{A}$ and $\mathrm{B}$ variants, in that Icelandic milk had much higher levels of $\beta$-lactoglobulin A $(55.2 \pm 1.1)$ than Scandinavian milk $(42.0 \pm 1.3)$.

Table 2 compares fatty acid content in Icelandic milk versus milk from the other Nordic countries. Significant differences were found in the content of $n-3$ and $n-6$ fatty acids (Table 2 ). The $n-6 / n-3$ ratio was lower in the Icelandic milk $(2.1 \pm 0.2$ vs $4.7 \pm$ $1.1, p<0.001)$.

For nitrates, no significant difference was found ( $p=0.228$, equal variances not assumed), although the Icelandic mean was higher than that of the other Nordic countries $\left(6.6 \pm 2.3\right.$ vs $3.6 \pm 0.5 \mu \mathrm{g} \mathrm{g}^{-1}$ dry milk powder).

\section{Discussion}

This study shows significant differences in genetic variants of proteins and fatty acid content between Icelandic milk and milk from the other Nordic countries. Regarding the $\beta$-caseins, the differences found in fractions of genetic variants are supported by earlier studies $(1,2)$, in which differences were even greater. These studies were performed in the mid- to late 1990s and it is obvious that the milk composition in the other Nordic countries has changed since then. The change has occurred mainly in Norwegian milk, which is now more

Table 2. Fatty acids in Icelandic $(n=9)$ versus Nordic milk $(n=12)$

\begin{tabular}{lccr}
\hline & Iceland & $\begin{array}{l}\text { Other Nordic } \\
\text { countries }\end{array}$ & \multicolumn{1}{c}{$\boldsymbol{p}$} \\
& & \multicolumn{1}{c}{. } & \\
\hline Linolenic acid & $0.677 \pm 0.020$ & $0.529 \pm 0.033$ & $<0.001$ \\
EPA & $0.140 \pm 0.015$ & $0.042 \pm 0.005$ & $<0.001$ \\
DHA & $0.218 \pm 0.018$ & $0.042 \pm 0.005$ & 0.347 \\
Very long-chain n-3 & $0.895 \pm 0.033$ & $0.571 \pm 0.034$ & $<0.001$ \\
n-3 & $1.80 \pm 0.117$ & $2.50 \pm 0.207$ & 0.015 \\
Linoleic acid & $0.094 \pm 0.014$ & $0.155 \pm 0.025$ & 0.064 \\
Arachidonic acid & $1.89 \pm 0.131$ & $2.67 \pm 0.226$ & 0.014 \\
n-6 & $3.80 \pm 0.061$ & $3.25 \pm 0.070$ & $<0.001$ \\
Lauric acid & $12.4 \pm 0.062$ & $10.7 \pm 0.107$ & $<0.001$ \\
Myristic acid & $29.0 \pm 0.225$ & $29.0 \pm 0.299$ & 0.949 \\
Palmitic acid & $9.81 \pm 0.115$ & $11.59 \pm 0.202$ & $<0.001$ \\
Stearic acid & $67.0 \pm 0.250$ & $65.7 \pm 0.326$ & $<0.007$ \\
Saturated fatty acids & $0.64 \pm 0.02$ & $0.57 \pm 0.02$ & 0.030 \\
CLA & & & \\
\hline
\end{tabular}

Data are shown as mean $\pm S E M$ in wt\% of total fatty acids.

EPA: eicosapentaenoic acid; DHA: docosahexaenoic acid; CLA: conjugated linoleic acid. similar to the Icelandic milk than it was in the 1990s. The A1 and B $\beta$-casein variants have been suggested to be involved in the pathogenesis of DM1 , in contrast to the A2 variant. Animal studies have suggested $\beta$-casein $\mathrm{A} 1$ to be diabetogenic and the $\mathrm{B}$ variant is thought to act similarly $(2,15,16)$. However, more recent animal feeding studies found it unlikely that the consumption of $\beta$-casein A1 has a significant influence on DM-1 (17). The pathogenesis of DM-1 is complex and considered to result from both genetic and environmental factors. The insulin-producing $\beta$-cells of the pancreas are destroyed by an autoimmune process, often at an early age. A possible explanation for the involvement of $\beta$-casein $\mathrm{A} 1$ and $\mathrm{B}$ in the pathogenesis of DM-1 is that they, as the result of a point mutation, differ from $\beta$-casein A2 in one amino acid (residue 67), thus rendering other cleavage products after digestion by the intestinal enzymes (2). Among these products, special emphasis has been placed on the opioid receptor ligand $\beta$-casomorphin-7, shown in some experiments to inhibit immune cell function (15). A study from New Zealand found correlations between $\beta$-casein $A 1$, but not $\beta$-casein $B$, and death from ischaemic heart disease (18), although this has not been supported by other studies (19). The possible effects of the other casein variants, $\alpha$ and $\kappa$, on health are yet to be clarified.

A Finnish study showed elevated amounts of anti- $\beta$-lactoglobulin immunoglobulins in patients with DM-1 (20), suggesting a possible role of these proteins in the pathogenesis of DM-1. The present study showed significant geographical differences regarding the $\beta$-lactoglobulin fractions $\mathrm{A}$ and $\mathrm{B}$, with Iceland being higher in $\mathrm{A}$ and thus lower in $\mathrm{B}$.

The Icelandic milk is high in $\mathrm{n}-3$ fatty acids and its ratio of $n-6 / n-3$ is less than half of that in milk from the other Nordic countries. n-3 fatty acids are thought to have a cardioprotective effect, and there are some data on possible effects on the prevalence of diabetes mellitus type 2 (DM-2) (21).

The total amount of very long-chain n-3 fatty acids was about five times higher in the Icelandic milk. These include eicosapentaenoic acid (EPA) and docosahexaenoic acid (DHA), which are direct precursors of prostaglandins, thromboxanes and leukotrienes, and thus influence a variety of processes in the human body linked with disease, e.g. inflammation and hypertension. They can also be synthesized from the shorter n-3 fatty acids, although this may not be quantitative because 
elongation is a limiting step. In cow's milk, the very long-chain fatty acids can originate both from within the cow's metabolism and from the animals' diet. A plausible explanation for the high amounts found in milk from Icelandic cattle is that they are fed fishmeal for part of the year.

The total amount of saturated fatty acids was significantly higher in the Icelandic milk, although the relative difference was only a few per cent. A high intake of saturated fatty acids is known to have a negative effect on plasma lipoprotein profiles by raising the low-density lipoprotein (LDL) levels, and is associated with cardiovascular disease risk (22), DM-2 and the metabolic syndrome. It is questionable, however, whether these differences are clinically significant, as the relative difference is quite small.

The amount of CLA was also significantly higher in the Icelandic milk, although seasonal variations were high. This difference is supported by earlier, unpublished Icelandic studies. CLA is proven to reduce abdominal fat slightly and to increase lean body mass (23).

This study is the first to examine thoroughly the differences between Icelandic cow's milk and milk from the other Nordic countries. The lower amounts of $\beta$-casein A1 and B found in Icelandic milk point toward the possibility of health benefits in comparison to milk from the other Nordic countries. The role of $\beta$-lactoglobulins in diabetes and public health issues needs further clarification, and the higher n-3, very long-chain n-3 in Icelandic milk may provide health benefits. The other four Nordic countries have a higher prevalence of DM-2 and hypertension, as well as higher mortality from coronary heart disease (24-27). This is surprising taking into account the high prevalence of overweight and obesity in Iceland, which is among the highest in Europe (28).

Over the years, cattle breeding has been extensively performed in many regions of the world, with consequential differences in milk composition internationally. With regard to protein fractions, the vast majority of cow's milk is thought to resemble that of the other Nordic countries rather than Icelandic milk.

Although this study was extensive, and compared Icelandic values for milk constituents to the mean values from the other Nordic countries, further comparisons should be done, including possible differences between these countries. Icelandic full- fat milk has $3.9 \%$ fats, which seems high in comparison to full-fat milk from the other Nordic countries. Studies adjusting for fats and national dairy product consumption are needed to shed more light on the influence of the composition of cow's milk on public health.

In conclusion, the higher fractions of $\mathrm{A} 2 \beta$-casein and $\beta$-lactoglobulin $\mathrm{A}$, and the higher amounts of n-3 fatty acids in Icelandic milk indicate health benefits despite a slightly higher amount of saturated fatty acids. Health researchers must be aware of the changes in milk composition as a result of cattle breeding. Further knowledge in this area may provide the possibility of eventually altering cattle breeds, thus yielding a milk with substantial benefits to public health.

\section{References}

1. Thorsdottir I, Birgisdottir BE, Johannsdottir IM, Harris DP, Hill J, Thorsson AV. Different beta-casein fractions in Icelandic versus Scandinavian cow's milk may influence diabetogenicity of cow's milk in infancy and explain low incidence of insulin-dependent diabetes mellitus in Iceland. Pediatrics 2000; 106: 719-24.

2. Elliott RB, Harris DP, Hill JP, Bibby NJ, Wasmuth HE. Type I (insulin-dependent) diabetes mellitus and cow milk: casein variant consumption. Diabetologia 1999; 42: $292-6$.

3. Birgisdottir BE, Hill JP, Harris DP, Thorsdottir I. Variation in consumption of cow milk proteins and lower incidence of type 1 diabetes in Iceland vs the other 4 Nordic countries. Diabetes Nutr Metab 2002; 15: 2405.

4. Lien S, Kantanen J, Olsaker I, Holm LE, Eythorsdottir E, Sandberg K, et al. Comparison of milk protein allele frequencies in Nordic cattle breeds. Anim Genet 1999; 30: $85-91$.

5. Jacques F, Klemetsdal G. Nordic dairy cattle comparison for milk production by using a mixed linear model approach. Livestock Prod Sci 1990; 26: 91-106.

6. Liinamo AE. Breeding for carcass traits in dairy cattle. Academic Dissertation, Dept of Animal Science, University of Helsinki, Finland; 2000.

7. Christopherson S, Glass RL. Preparation of milkfat methyl esters by alcoholysis in an essentially nonalcoholic solution. J Dairy Sci 1969; 52: 1289-90.

8. Richardson RK. Improvement in accuracy and reliability of FAME analysis of milkfat and milkfat-containing blends. Fats for the Future II Conference New Zealand, 12-17 February 1989.

9. Ackman RG, Sipos JC. Application of specific response factors in the gas chromatographic analysis of methyl esters of fatty acids with flame ionization detectors. $\mathbf{J}$ Am Oil Chem Soc 1964; 41: 377-8.

10. Bannon CD, Craske JD, Hilliker AE. Analysis of fatty acid methyl esters with high accuracy and reliability. V. 
Validation of theoretical response factor of unsaturated esters in the flame ionisation detector. J Am Oil Chem Soc 2001; 63: 105-10.

11. Bobe G, Beitz DC, Freeman AE, Lindberg GL. Separation and quantification of bovine milk proteins by reversed-phase high-performance liquid chromatography. J Agric Food Chem 1998; 46: 458-63.

12. Recio I, Perez-Rodriguez ML, Ramos M, Amigo L. Capillary electrophoretic analysis of genetic variants of milk proteins from different species. J Chromat A 1997; 768: 47-56.

13. Elgar DF, Norris CS, Ayers JS, Pritchard M, Otter DE, Palmano KP. Simultaneous separation and quantitation of the major bovine whey proteins including proteose peptone and caseinomacropeptide by reversed-phase high-performance liquid chromatography on polystyrene-divinylbenzene. J Chromat A 2000; 878: 183-96.

14. Kinghorn NM, Norris CS, Paterson GR, Otter DE. Comparison of capillary electrophoresis with traditional methods to analyse bovine whey proteins. J Chromat A 1995; 700: 111-23.

15. Elliott RB, Wasmuth HE, Bibby NJ, Hill JP. The role of $\beta$-casein in the induction of insulin-dependent diabetes in the non-obese diabetic mouse and humans. In: Seminar on Milk Protein Polymorphism, IDF Special Issue No. 9702. Brussels: International Dairy Federation; 1997. p. 445-53.

16. Padberg S, Schumm-Draeger PM, Petzoldt R, Becker F, Federlin K. The significance of A1 and A2 antibodies against beta-casein in type-1 diabetes mellitus. Dtsch Med Wochenschr 1999; 124: 1518-21.

17. Beales PE, Bibby N, Elliott RB, Flohe S, Gruber H, Hill JP, et al. A multi-centre, blinded international trial of the effect of A1 and A2 $\beta$-lactoglobulin variants on diabetes incidence in two rodent models of spontaneous type-1 diabetes. Diabetologia 2002; 45: 1240-6.

18. McLachlan CN. Beta-casein A1, ischaemic heart disease mortality, and other illnesses. Med Hypotheses 2001; 56: 262-72.

19. Hill JP, Crawford RA, Boland MJ. Milk and consumer health: a review of the evidence for a relationship between the consumption of $\beta$-casein A1 with heart disease and insulin-dependent diabetes mellitus. Proc N Z Soc Anim Prod 2002; 62: 111-4.
20. Vaarala O, Klemetti P, Savilahti E, Reijonen H, Ilonen J, Akerblom HK. Cellular immune response to cow's milk beta-lactoglobulin in patients with newly diagnosed IDDM. Diabetes 1996; 45: 178-82.

21. Sirtori CR, Galli C. n-3 fatty acids and diabetes. Biomed Pharmacother 2002; 56: 397-406.

22. Lichtenstein AH. Dietary fat and cardiovascular disease risk: quantity or quality? J Womens Health 2003; 12: 109-14.

23. Riserus U, Smedman A, Basu S, Vessby B. CLA and body weight regulation in humans. Lipids 2003; 38 : 133-7.

24. Vilbergsson S, Sigurdsson G, Sigvaldason H, Hreidarsson AB, Sigfusson N. Prevalence and incidence of NIDDM in Iceland: evidence for stable incidence among males and females 1967-1991 - the Reykjavik Study. Diabetes Med 1997; 14: 491-8.

25. Wolf HK, Tuomilehto J, Kuulasmaa K, Domarkiene S, Cepaitis Z, Molarius A, et al. Blood pressure levels in the 41 populations of the WHO MONICA Project. J Hum Hypertens 1997; 11: 733-42.

26. Chambless L, Keil U, Dobson A, Mahonen M, Kuulasmaa K, Rajakangas AM, et al. Population versus clinical view of case fatality from acute coronary heart disease: results from the WHO MONICA Project 19851990. Multinational MONItoring of Trends and Determinants in CArdiovascular Disease. Circulation 1987; 96: 3849-59.

27. Ecological analysis of the association between mortality and major risk factors of cardiovascular disease. . The World Health Organization MONICA Project. Int J Epidemiol 1994; 23: 505-16.

28. Thorgeirsdottir H, Steingrimsdottir L, Olafsson O, Gudnason V. Trends in overweight and obesity in 4564 year old men and women in Reykjavik 1975-1994. Icelandic Med J 2001; 87: 699-704.

Inga Thorsdottir

Unit for Nutrition Research, Landspitali-University Hospital, IS|0| Reykjavik, Iceland

E-mail: ingathor@landspitali.is 